Article

\title{
Tourist Maps to Capture Place Identity During Disruptive Events: The Case of Beirut
}

\author{
Laura Simak \\ Department of Urban Design and Urban Development, Technische Universität Berlin, Germany; \\ laura.simak1313@gmail.com
}

Submitted: 31 July 2021 | Accepted: 30 December 2021 | Published: 23 February 2022

\begin{abstract}
Between October 2019 and August 2020, Beirut underwent an unprecedented sequence of events in its recent history, starting with massive anti-government protests, followed by an economic and financial meltdown, coupled with the Covid-19 pandemic, and ending with an explosion in the port that devastated large parts of the metropolis. As a citynewcomer and urban design student from the Technische Universität Berlin, researching the theme of borders in fragmented cities for my master's thesis, I was faced with a city-in-flux for 200 days, where mobility restrictions and safety measurements, as impacted by Covid-19, led to the exclusion of field investigation as a primary source of information. Hedging against the limitations imposed, I developed and tested a methodology that involves analyzing tourist maps as an alternative reconnaissance tool for urban designers. On the example of the Beirut port blast area, namely Gemmayze and Mar Mikhael, this study includes the decomposition of three tourist maps of Beirut in order to extract and verify their data and, furthermore, reconstruct the identity and image of the neighborhoods through this secondary resource. The analytical framework brings together the theories of place and space that exist in the different disciplines of spatial studies: social science's The Production of Space by Lefebvre; urban geography's Place and Placelessness by Relph; environmental psychology's The Psychology of Place by Canter; and urban design's Components of the Sense of Place by Punter and Montgomery. By exemplifying what it means to be a foreigner and a researcher exploring tourist maps in Beirut during this particular time, this article aims to encourage interdisciplinary approaches in urban studies and to critically reflect on atypical and underutilized tools for studying contemporary cities under extraordinary conditions of change.
\end{abstract}

\section{Keywords}

Beirut port blast; city-in-flux; map deconstruction; place identity; spatial studies; tourist maps; urban design

\section{Issue}

This article is part of the issue "Urbanisation, Crisis, and Resilience: The Multiple Dimensions of Urban Transformation in Beirut, Lebanon" edited by Liliane Buccianti-Barakat (Saint Joseph University) and Markus Hesse (University of Luxembourg).

(C) 2022 by the author(s); licensee Cogitatio (Lisbon, Portugal). This article is licensed under a Creative Commons Attribution 4.0 International License (CC BY).

\section{Introduction}

Beirut's urban fabric is the visible reflection of the territory's history and cultural heritage of its citizens. Thirty years after the civil war and the city's former geographic division, Beirut remains a silent tension manifested in cognitive maps and behavioral patterns. The result is a spatial fragmentation due to both political and religious affiliation (Davie, 1994). However, between October 2019 and August 2020, Beirut experienced radical changes in its cityscape, its users' behavioral pat- terns, and its cognitive maps, provoked by an unpredictable and unique row of crises (Figure 1). October 17th, 2019 marks the start of the Lebanese Revolution, presenting a "city of political upheaval" dominated by contestation and reclamation. Induced by planned taxes on WhatsApp, gasoline, and tobacco, a series of massive anti-government protests accrued all across the country, followed by an economic and financial meltdown of Lebanon, threatening a total collapse of the economic system. This was the outcome of frustration and resistance against longstanding unemployment, economic 

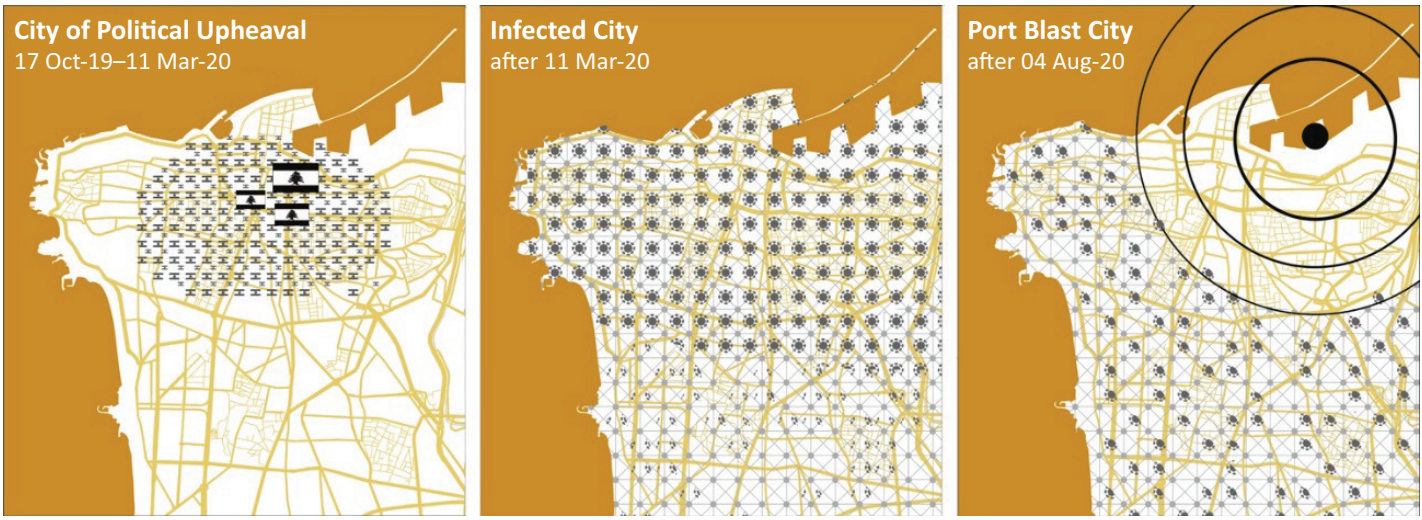

Figure 1. Beirut-in-flux: Illustrating and localizing the prevailing conflict in the capital in the three phases from October 2019 to August 2020.

stagnation, and extreme corruption in the public sector. The following "infected city," caused by the Covid-19 virus spreading worldwide, forced radical adjustments, changes in social and public life, and the lockdown of the country. In March 2020, Beirut started with the closure of schools and universities, a quarantine for residents, the closure of land and sea borders, and the shutdown of the international airport. Disrupted by the three-month lockdown, the revolution returned to the streets on June 6th, 2020. Beirut's international airport reopened on July 1st for commercial flights. Group gatherings remain prohibited and face masks and physical distancing were mandatory. The numerous crises at several levels found their peak in the port blast of August 4th, 2020, when two explosions hit the capital, ripping through the port of Beirut. The disaster was triggered by a large fire in warehouse number 12 next to the grain silos on the capital's port, leading to an initial explosion, followed by a series of smaller blasts, and one final colossal explosion. Caused by 2,750 tons of ammonium nitrate, the blast sent a supertonic wave radiating through the city and a vast reddish mushroom cloud in the capital's sky. The explosion destroyed property worth $\$ 10$ to 15 billion, causing the death of more than 200 people and leaving thousands injured and homeless.

In addition to the dramatic economic and social consequences, the numerous crises also negatively impacted the academic and scientific sectors. Enforced restrictions and security measures led to online-only education, seminars, and meetings, and the exclusion of field research, an essential routine for spatial analysis. As a German researcher intending to study the topic of intangible borders in fragmented Beirut within the frame of a master's thesis in urban design at the Technische Universität Berlin and the American University in Beirut, I was faced with the unexpected challenge of working remotely: As a foreigner and newcomer in Beirut, how can one analyze a city-in-flux from home? The unexpected circumstances triggered the search for an alternative tool to investigate the capital from a distance. Hedging against the imposed constraints and limitations, I developed and tested an unusual methodology for urban exploration by studying touristic maps of Beirut with the aim of reading the city's identity without onsite observations. The approach, first, requires deconstructing the maps into their various layers of content (Harley, 1989) and, second, translating their information into sketch maps (Lynch, 1960).

A tourist and an urban designer share a common concern for comprehending the identity of unfamiliar territories in a short time, the first for the pleasure of discovery, and the second for work. On the one hand, tourist maps are popular and efficient tools for way-finding and urban legibility as they have the advantage of shaping cognitive maps of the city for easy navigation by pin-pointing urban identity features in terms of landmarks, nodes, paths, districts, and edges (Lynch, 1960). On the other hand, as cartographic icons and bearers of culture themselves (Cosgrove, 2004), we expect them to comprise valuable information about place identity. Nevertheless, tourist maps are designed with a promotional agenda for the general non-specialized public. As such, they contain white lies (Monmonier, 1991) in form of missing data; this might be particularly verifiable in multi-sectarian and fragmented cities like Beirut (Saliba, 2020), where what is withheld is more significant than what is promoted in comprehending and entangling complexities of the urban realm.

But what does it really entail to be a tourist and a researcher at this difficult time in Beirut exploring touristic maps? Does a two-dimensional representation of the city reflect enough information about its place identity? Furthermore, how can effective data be extracted from maps and their content validated for urban planners? These questions formed the framework for the research topic to outline the merits and limitations of tourist maps for urban analysis and to define the significance of the secondary resources as tools to capture place identity. The approach is divided into three parts:

I. An interdisciplinary conceptual-analytical framework was designed to validate the data provided by the tourist maps. 
II. Tourist city maps were organized into three categories and, in the case of Beirut, deconstructed into their narrative layers to verify the contribution of each for professional city analysis.

III. To illustrate and assess the promoted cognitive map sketch maps of the blast area were generated by translating the tourist map information into the image elements named by Lynch (1969): paths, districts, edges, landmarks, and nodes.

\section{Conceptual-Analytical Framework (I)}

Beirut is a city with both a rich history and present. Under the logic of war, from 1975 to 1990, a demarcation line divided the city geographically and ideologically into a Christian East and a Muslim West. The pre-war tendency towards pluralism was replaced by a homogenization of the territory and segregation of the population (Genberg, 2002). The result was two districts with a distinct geographic identity (Davie, 1993, p. 10). Within each area, additional clusters emerged that were associated with a controlling militia. During these 15 years of war, sub-centers emerged in and around Beirut, giving a degree of autonomy and independence to the area in which they were located without centralizing functions (Davie, 1993). The spatial enclaves created by the war and still visible in the city can be grouped in terms of religious affiliation and sectarianism. Today, symbols such as the Virgin Mary in a glass box or the yellow flag of Hezbollah in addition to many more signs serve as territorial markers.

The compounding social environments of multisectarian and fragmented cities like Beirut, further disruptive events, and growing environmental concerns give weight to interdisciplinary approaches of diverse bodies in urban settings, crossing the blurry boundaries between design disciplines (Saliba, 2015). An urban designer's agenda is primarily concerned with "the quality of public space, both physical and sociocultural, and the creation (and management) of meaningful places for people to enjoy and use" (Carmona \& Tiesdell, 2007, p. 7). "Many attempts at grounding urban design theory in social sciences are leading to new understandings of urban space, locating it at the intersection of social theory, human geography, and cultural studies" (Saliba, 2015, p. 2). Since the early 1960s, an interdisciplinary field of environmental perception has emerged that focuses specifically on how people perceive environments by examining spatial perception and cognition, as well as the generation of meaning, symbols, and values in the urban environment through place experience. The understanding of place beside its physical component as what further distinguishes one place from another has been often described with identity, such as in the Latin concept of genius loci by Norberg-Schulz (1976), indicating an attachment to a spirit of place (Jackson, 1994, as cited in Carmona et al., 2003). Lynch
(1960) describes that the identity of a place is what constitutes its individuality and distinguishes it from other places. Nairn (1965, as cited in Relph, 1976, p. 45) complements that with the following:

There are as many identities of places, as there are people, for identity is in the experience, eye, mind, and intention of the beholder as much as in the physical appearance of the city or landscape. But while every individual may assign self-consciously or unselfconsciously an identity to a particular place, these identities are nevertheless combined intersubjectively to form a common identity.

Space and place together define the nature of urban geography (Tuan, 1979, p. 387). The basic dualism between place and space, as they are not the same but steadily connected, has been tangled by different perceptions in social sciences, geography, environmental psychology, and urban studies. Place is defined by location, as one "unit among others to which it is linked by a circulation net. Place, however, has more substance than the word location suggests: it is a unique entity, a special ensemble" (Lunkermann, 1964, as cited in Tuan, 1979, p. 387). Space, in contrast, is conceived as abstract geometries of distance, direction, size, shape, and volume. While "place" is associated with history, experience, and meaning through people (Tuan, 1979), "space" is seen as a contextual output for place, which only acquires meaning through the implementation of individuals, groups, or societies, and thus becomes place (Relph, 1976):

Space, then, [is] seen in distinction to place as a realm without meaning-as "a fact of life" which, like time, produces the basic coordinates for human life. When humans invest meaning in a portion of space and then become attached to it in some way... it becomes place. (Creswell, 2004, as cited in Castillo, 2017, p. 20)

An early attempt to define place through identity and opposing placelessness through its absence is the critical approach of the geographer E. Relph (1976). He describes places as an experienced phenomenon of the lived world, full of meaning, activities, and objects:

The meaning of place may be rooted in the physical setting, objects, and activities, but they are not a property of them-rather they are a property of human intentions and experiences....The three fundamental components of place are irreducible one to the other yet are inseparably interwoven in our experiences of places. (Relph, 1976, p. 47)

Accordingly, he delineates place in terms of physical setting, activity, and meaning. In counterpart to the concept of place, he defined placelessness as the loss of uniqueness in cultural space through the making of standardized landscape. 
Building on Relph's concept, Canter (1977), a wellknown environmental psychologist and pioneer of conceptual studies in urban design, created the first model in which he captures the urban environment as an assemblage of places, created through the interaction of activities, physical attributes, and conceptions. Canter's model has been reproduced in various versions (Figure 2). Punter (1991, as cited in Carmona et al., 2003) and Montgomery (1998, as cited in Carmona et al., 2003) located the place components within urban design thoughts. Correspondingly, the identity of place, or sense of place as named in Punter's model (1991, as cited in Carmona et al., 2003), includes the following place activities: behavioral patterns, pedestrian and vehicle flow, noise, and smell. Furthermore, he describes the physical setting of place as permeability, landscape, townscape and built form, and the meaning of place through legibility, cultural association, perceived functions, attractions, and qualitative assessments. Montgomery (1998, as cited in Carmona et al., 2003) builds on Punter's definition of the sense of place, adding that place activity can be also captured through its flow, vitality, diversity, café culture, pastimes, local traditions, events, opening hours, attractors, people watching, transactions base, and fine grain economy. The physical setting of place which he names the form can be analyzed through scale, intensity, permeability, landmarks, space to building ratios, stock, vertical grain, and public realm. The last component, the image of place Montgomery describes by cognition, perception, and information, contains symbolism and memory, imagination and legibility, sensory experience and associations, knowledgeability, and receptivity.

Lefebvre imprints a social characteristic on space claiming that "space considered in isolation is an empty abstraction; likewise, energy and time" (Lefebvre, $1974 / 1991$, p. 12). Urban space is more than a "containerlike-frame" of distance, direction, size, shape, and volume as it gets produced, as well as reproduces its conditions of existence-"containing [social] relations of repro- duction as well as relations of production" (Lefebvre, $1974 / 1991$, p. 73). The space of a city, in his conclusion, is a product "composed by people, by well-defined groups" (Lefebvre, 1974/1991, p. 74) and cannot be compared with a static object. It is a social construct created through social relations that he characterized as the triad of spaces: the navigation of spatial practices in the perceived space, the signs and symbols of the lived space, and the people-less and conceptualized space of the conceived dimension.

Lefebvre's "spatial turn" (Cuff et al., 2020) stresses the importance of space in capturing the urban. Thus, space and place are not the same. Lefebvre's theory of social space and the urban planning approach that defines the sense of place overlap in certain aspects. The contribution in this study is the synthesis of the urban design identity model with the concept of Lefebvre's social space. This linking is based on Lefebvre's conception "that any reality is related methodologically and theoretically to the three general concepts of form, structure, and function" (Lefebvre, 1974/1991, p. 369). In this context, Lefebvre first allocates his perceived dimension to form, stating: "Form corresponds to the moment of communication, hence to the realm of the perceived" (Lefebvre, 1974/1991, p. 369). He describes the perception of form not in a material meaning but as the spatial interpretation which can be observed in the urban through place-activity. It is the vital component of spatial negotiation that summarizes all environmental and social interactions, behavior, and navigation within a particular place (Canter, 1977, position 20464). Designated also as place appropriateness, Canter states that there are clearly defined patterns of relationships and associated appropriate behavior within a place (Canter, 1977, position 18097). Accordingly, the form of a place is further compounded if the range of activities is diverse or the action associated within it is subjective and, therefore, exchangeable. Second, Lefebvre allocates the conceived dimension under the headline of structure.

$\begin{array}{ccccc}1955 & 1977 & 1979 & 1991 & 1998 \\ \text { Camus } & \text { Relph } & \text { Canter } & \text { Punter } & \text { Montgomery } \\ \text { philosophy } & \text { geography } & \text { psychology } & \text { urban design }\end{array}$

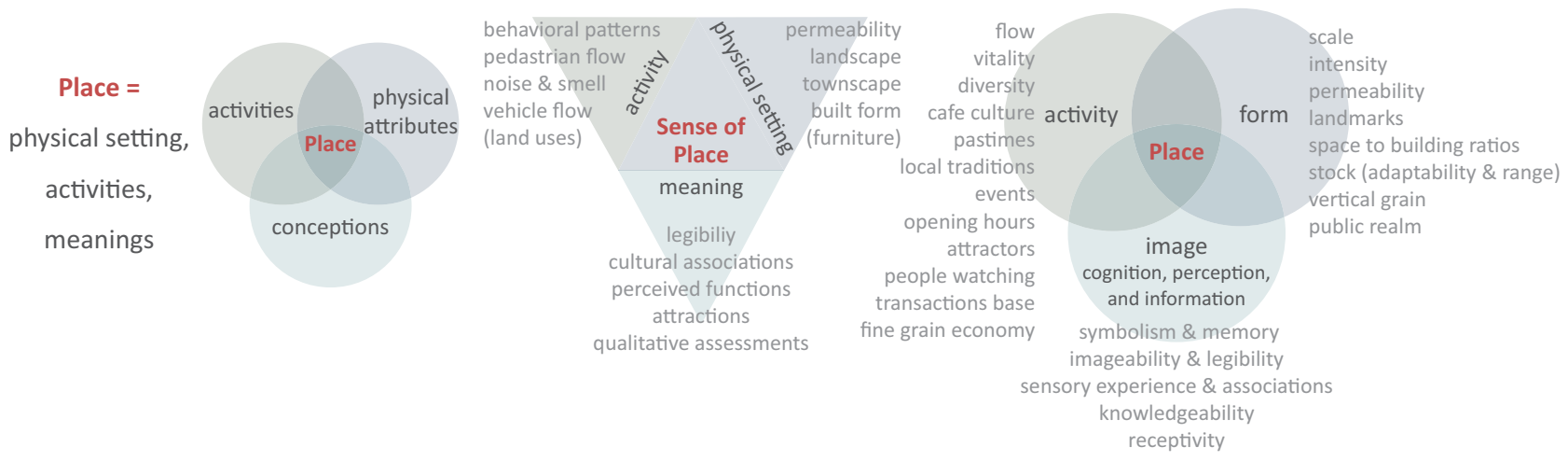

Figure 2. Development of (sense of) place diagram. Sources: Reconstructed by the author based on Canter (1977) and Carmona et al. (2003). 
As per Lefebvre (1974/1991, p. 389), "structure is conceived and implies a representation of space." It is the medium for objects as well as an object itself-it is a visual space (Lefebvre, 1974/1991, p. 361). As a representation of space, this dimension intervenes in the urban through constructions, projects, and architecture which indicates a spatial materiality. Therefore, it can be linked to the physical setting of place. Determining the structure of the perceived space, it plays a role in the social and political practice as it establishes relations between objects and people in represented spaces. Third, Lefebvre allocates his lived dimension to function, stating that "function is carried out, effectively or not and corresponds to the directly experienced in representational space" (Lefebvre, 1974/1991, p. 27). The only products of the lived dimension-the symbols, images, and signs-overlay the physical and transmit the spatial meaning: "These [symbolic works] are often unique; sometimes they set in train 'aesthetic' trends and, after a time, having provoked a series of manifestations and incursions into the imaginary, run out of steam" (Lefebvre, 1974/1991, p. 42). Its origin is in the users, created through history and environmental perception. As such, the lived-function or lived-meaning is connected to the conceptualizations of place. The result can be illustrated in a model presenting the components for the spatial identity: spatial interpretation (perceived form), spatial materiality (conceived structure), and spatial meaning (lived function; Figure 3).

\section{Deconstruction of the Maps (II)}

A map says to you, "read me carefully, follow me closely, doubt me not.... am the earth in the palm of your hand. Without me, you are alone and lost." And indeed you are. Were all the maps in this world destroyed and vanished under the directions of some malevolent hand, each man would be blind again, each city be made a stranger to the next, each landmark becomes a meaningless signpost pointing to nothing. (Harley, 1989, p. 1)

\subsection{Classification of Mental Maps}

In their various roles, maps have different functions. As guides, they provide spatial information, help us navigate, mark territories, and communicate information. As a tool, they serve analysis, make growing cities manageable, and guide developments. Maps create a common basis for future decisions and projections of design plans. As a medium, they store knowledge, construct people's views of the world, constitute nations and identity and, as a strategic tool, they serve as weapons. Cartography is the science and practice of drawing maps; it describes the achievement of isolating select spatial information, modeling it, and encoding it in a two-dimensional representation.

Hence, the history of urban cartography is old, the pace of development of alternative mapping techniques and conceptual exploration is slow (Harley, 1989). Maps of urbanizing cities in the 16th century were not initially intended to be way-finding instruments but ceremonial and decorative images depicting the complex spatial and social totality of the city. In the 18th century, legibility became the overriding goal of urban mappings (Cosgrove, 2004), which implied cartographic objectivity and accuracy in the map-making process, to eliminate evidence of human interventions between survey instruments and printed images. By the mid-20th century, urban mapping was no longer a process associated with planning and design professions. The exploration of the "city as performance art" (Cosgrove, 2004, p. 56) and the analysis of spatial relationships and decisions through cognitive maps were commissioned by artists and various scholars concerned with urban space. Cognitive mapping is nowadays a standard tool in planning arts and social sciences. Described as "environmental and mental image" by Lynch (1960) as well as Lefebvre (1974/1991), "cognitive schemata" (Lee, 1968, as cited in Kitchen, 1994), "spatial schemata" (Neisser, 1976), "a map in the head" or "mental map" (Canter, 1977), "cognitive image" (Lloyd, 1982, as cited in Kitchen, 1994), or "mental representation" (Gale, 1982), current understanding
Urban Design: Sense of Place (Punter/Montgomery)

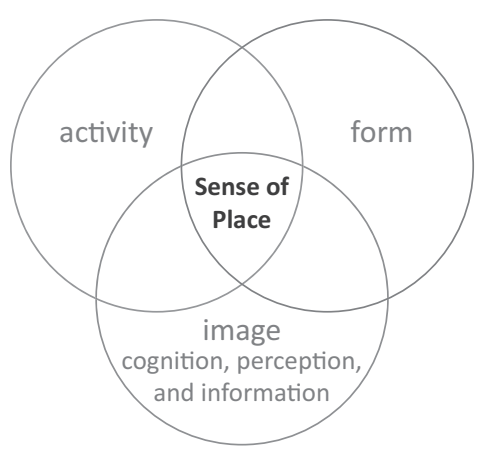

Social Sciences: Social Space (Lefebvre)

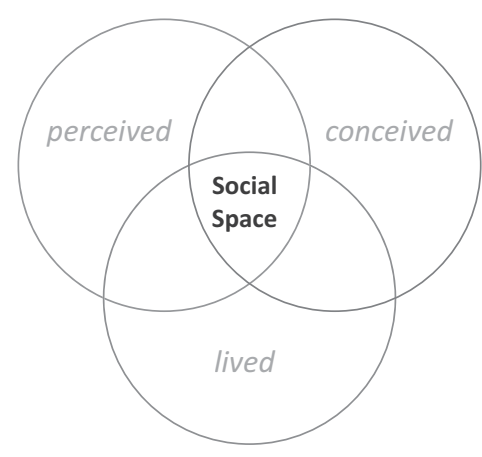

Interdisciplinary: Spatial Identity

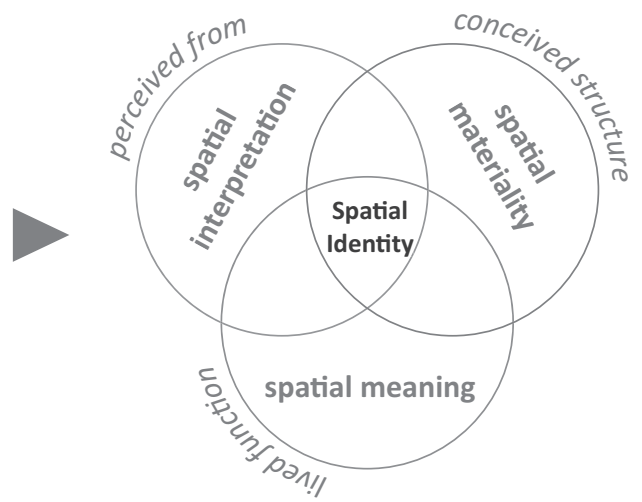

Figure 3. Identity models: Synthesis of Lefebvre's social space concept with the urban design model of the sense of place. 
suggests that neither a uniform terminology nor a distinction between different agendas in the process of mapmaking exists.

Undertaken by a personal agenda, the essentialcognitive map is the personal point-of-view perception of what the environment contains (Lynch, 1960). It is a mental construct that we use to understand and know the environment, leading to spatial decisionmaking and behavioral patterns. Essential cognitive mapping is a method for spatial problem solving due to simple way-finding, orientation, and organization in space. It is a product of environmental perception created by gathering, organizing, and interpreting spatial information through the human sensory system-vision, hearing, smell, and touch-and the four dimensions of perception-cognitive, affective, interpretative, and evaluative (Carmona et al., 2003). The essential cognitive map describes the environmental cognition (Canter, 1977), defined as "the knowledge and internal or cognitive representation of the structure, entities, and relations of space; in other words, the internalized reflections and reconstruction of space in thought" (Hart \& Moore, 1973, as cited in Kitchen, 1994, p. 1).

The approach of the avant-garde art movement Situationists International, a group of artists, activists, and thinkers in the 1960s, presented a whole new category of cartographic products, underlying a philosophicalcritical agenda. In this evolved sense, cognitive mapping is a tool to illustrate complex spatial interrelations and uncover hidden traces of lived context (Cosgrove, 2004) in order to initiate a debate on how urban space is experienced and known and, furthermore, how it should be mapped. Their work focused on social practices and formations in everyday surroundings, oriented towards experimentation in contact with the real.

Lynch's methods, known as mental-mapping related to the spatial encoding of information in memory and the visualization of cognitive maps, underlie a professional agenda to explore the environmental-cognitive system and how people perceive space (Canter, 1977, position 7565). Studies regarding examining people's cognitive maps seek to understand human's interactions and identities with their environment in terms of their cognitive system (Canter, 1977, position 5639).

\subsection{Classification of Tourist Maps}

Driven by societies' growing desire to explore foreign places through traveling, maps created for tourism form one of the most common and diverse cartographic documents. The tourist map is a much-favored device, designed to be useful and popular (Monmonier, 1991). Its double-sided characteristic of informing and impressing its audience is the result of both objective and subjective mapping techniques. As a tool for orientation, it provides the reader with sufficient, though adequately simplified topographic content, and functions as a location marker and way-finding instrument for guiding the observer to a physical destination. However, tourist maps are more than just aids to pin-point landmarks and cultural attractions of the city: They are cartographic icons and bearers of culture themselves (Cosgrove, 2004). As a promotional device, map elements other than topographic content perform a different function. By promoting the city's branding, local rules, and inside knowledge, the tourist map points towards the city's intrinsic logic to provide outsiders with an inside view of the local.

Building on the existing map sorting by Jancewicz and Borowicz (2017), who grouped tourist maps after type and aim of tourism, I added the set of tourist city maps in favor of this research. The tourist city maps can be further categorized by their means of exploration, of which there are three identified ways a city can be explored: (a) self-guided, (b) guided via bus, and (c) guided walking tours. The first category contains maps for travelers discovering the city self-guided. The tour can be performed afoot or by bicycle or car. Maps for self-guided city explorations are often part of travel guides and guidebooks, tourist atlases, and online based for the display on mobile devices. The second describes a guided discovery in a group via sightseeing buses, following a fixed route through the city with arranged stops at major landmarks and tourist attractions. The third group summarizes the city discovery on a guided tour by foot or bicycle, led by several private operators, local tourist offices, and global platforms. Mainly fee-based, walking-city tours are navigated by a guide who tells the city's history and provides background information to its audience.

Resulting from the sorting the research scope was limited to three maps of Beirut: (a) Lonely Planet map for self-guided city exploration; (b) City Sightseeing map for guided tours via bus; and (c) Best of Beirut map for guided walking trips (Figure 4).

Each map follows its own approach and objective in terms of the target audience, the mobility system it promotes, and the content focus. The Lonely Planet is one of the world's leading providers of travel books and information. The travel guide targets subcultures and young people, and the mobility system it promotes is mainly focused on private cars and pedestrians. Supported by a clear and legible display, its map provides information for cultural tourism. The zoom maps entail detailed information about the internal structure and functions of the districts. Furthermore, the written information in additional texts promotes the logic of the local. According to the website of City Sightseeing, the potential customers are tourists of all categories, age groups, socio-economic status, and nationalities. The mobility system, a fixed route through the city by hop-on hop-off bus, determines the complete information of the city map. Based on mobility, the focus is set on routes and points of interest. As a result, the map shows one way to see the city and simplifies its complexity. The Best of Beirut map is created by Zawarib, the leading cartography company in the Middle East and based in Beirut. On its website, the company 


\section{COGITATIO}

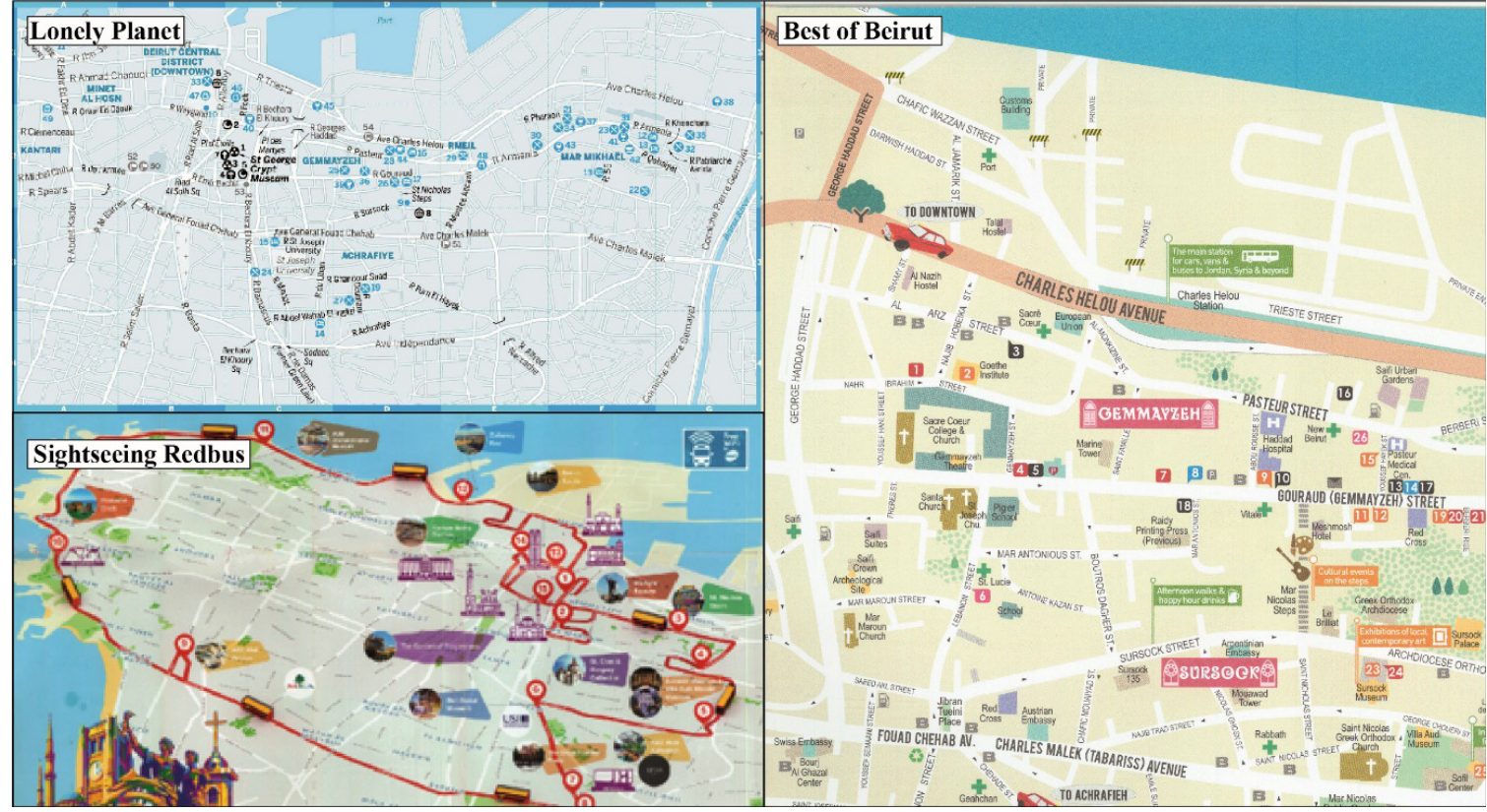

Figure 4. Tourist city maps of Beirut. Sources: City Sightseeing Worldwide (2021); Ham et al. (2019, p. 1015; Lonely Planet); Zawarib (2020; Best of Beirut).

advertises that it creates visually meaningful maps to discover a city and explore unusual places, the target groups of which are newcomers, visitors, and residents. With the focus set on pedestrians and cyclists, the zoom maps feature detailed route data. The map is intended to provide insider information to outsiders, and, therefore, the associated emphasis is on districts and nodes.

To extract the data of the maps, they were subsequently deconstructed into the various layers of content, referred to by Harley (1989) as text:

The word "text" is deliberately chosen. It is now generally accepted that the model of text cannot be applied only to literary texts. To texts that do not come from books, such as musical compositions and architectural structures, we can confidently add the graphic texts we call maps. (McKenzie, 1986, as cited in Harley, 1989, p. 7)

Viewing maps as text suggests a shift in perspective to "recognize narrative qualities of cartographic repre- sentation" (Harley, 1989, p. 7). Tourist maps are composed by three narrative layers. The first text contains the geographic data. It is the base map providing route and area information and serving as an aid for orientation. The second text displays location data through additional icons and symbols providing the reader with the program of the local. The third text includes promotional data through supplementary information around the map, such as recommendations, diagrams, and figures supporting the image and logic of the place.

For the analysis, the geographical scope was narrowed down to the port blast area (Figure 5), namely Gemmayze and Mar Mikhael, famous places for locals and tourists.

To verify the suitability of the extracted data as a reference for spatial identity (spatial materiality, spatial meaning, and spatial interpretation), the content of the three layers is reviewed with the help of the analytical and conceptual framework (Table 1). The analysis leads to three main findings. First, information about spatial materiality is primarily found in the first and second texts
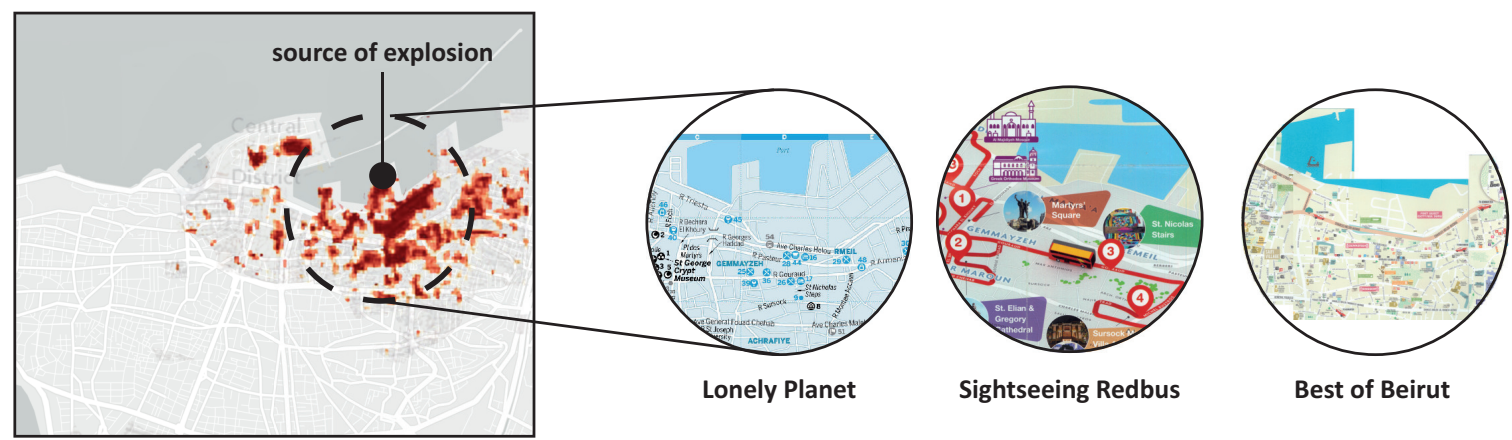

Figure 5. Port blast area. 
Table 1. Map data as a reference for spatial identity.

\begin{tabular}{|c|c|c|c|}
\hline $\begin{array}{l}\text { Component of } \\
\text { Spatial Identity }\end{array}$ & First Text & Second Text & Third Text \\
\hline $\begin{array}{l}\text { Spatial } \\
\text { Materiality }\end{array}$ & $\begin{array}{l}\text { Land use (port city, main road } \\
\text { separates sea and land, } \\
\text { no park). } \\
\text { Built form of churches, } \\
\text { hospitals, and schools. }\end{array}$ & $\begin{array}{l}\text { Landmarks (Sursock Museum, } \\
\text { St George Crypt Museum, Cardo } \\
\text { Maximus, Martyrs Square, } \\
\text { St Nicolas Stairs). } \\
\text { Program (port, four landmarks, } \\
18 \text { cultural attractions, four cafés, } \\
13 \text { restaurants, seven hotels and } \\
\text { hostels, nine shopping boutique, } \\
\text { six schools, } 11 \text { churches, Charles } \\
\text { Helou Bus Station, House for } \\
\text { European Union, two embassies, } \\
\text { Ministry of Foreign Affairs, } \\
\text { Electricité du Liban, one hospital, } \\
\text { nine pharmacies, } 20 \text { ATMs, } \\
13 \text { parking spaces, and } \\
\text { a post-office). }\end{array}$ & \\
\hline $\begin{array}{l}\text { Spatial } \\
\text { Meaning }\end{array}$ & $\begin{array}{l}\text { Legibility (waterfront, road } \\
\text { connections east-west and } \\
\text { northwest, intrinsic character } \\
\text { of the district, open public } \\
\text { places, cultural hop, Beirut } \\
\text { walking tour). } \\
\text { Attractions (landmarks, } \\
\text { museums, archaeological } \\
\text { display, galleries, religious } \\
\text { sites, art, nightlife). }\end{array}$ & & $\begin{array}{l}\text { Symbols, images, and signs } \\
\text { (iconic hotels, iconic stairways, } \\
\text { iconic restaurants, Parisian-style } \\
\text { décor, décor in rich art and } \\
\text { antiques, industrial chic, } \\
\text { Lebanese artisans). } \\
\text { Cultural association (fascinating } \\
\text { nexus point of Middle East \& } \\
\text { West, tradition and modernity). } \\
\text { Perceived functions (mountain } \\
\text { vista, community feeling, } \\
\text { exhilarating atmosphere, } \\
\text { live music). }\end{array}$ \\
\hline \multirow[t]{4}{*}{$\begin{array}{l}\text { Spatial } \\
\text { Interpretation }\end{array}$} & & $\begin{array}{l}\text { Transaction base (gastronomy, } \\
\text { leisure locations, museums, } \\
\text { café culture). }\end{array}$ & $\begin{array}{l}\text { Behavior patterns and routines } \\
\text { (afternoon walks, happy hour, } \\
\text { lunch break). }\end{array}$ \\
\hline & & $\begin{array}{l}\text { Attractors (gastronomes, locals, } \\
\text { expats, art scene, tourist, } \\
\text { foodies). } \\
\text { Vitality (two stops of walking } \\
\text { tour, cultural hot spot, high } \\
\text { density of bars and restaurants, } \\
\text { four sightseeing spots). }\end{array}$ & $\begin{array}{l}\text { Flow (crowded, street life). } \\
\text { Local events and traditions } \\
\text { (nightlife, rooftop bars, artistic } \\
\text { projects, open-air events, local } \\
\text { hangouts, film festival, national } \\
\text { cuisine, fashion conscious, } \\
\text { multilingual). }\end{array}$ \\
\hline & & & $\begin{array}{l}\text { Opening-hours (restaurants and } \\
\text { cafés: } 8 \text { am-12 pm, } \\
\text { clubs: } 6 \mathrm{pm}-3 \mathrm{am} ; \\
\text { shopping: } 9: 30 \mathrm{am}-7 \mathrm{pm} ; \\
\text { museums: } 9 \text { am- } 6 \mathrm{pm} \text { ). }\end{array}$ \\
\hline & & & $\begin{array}{l}\text { Noise and smell (music, traffic, } \\
\text { people, cuisine). }\end{array}$ \\
\hline
\end{tabular}


of the maps through indicators for land use, the program of the local, landmarks, and legibility. Second, data about the spatial meaning is given in the first and third texts by data about symbols, images, signs, cultural associations, perceived functions, and descriptions. Third, evidence about the spatial interpretation is presented by the second and third texts through data about transaction base, behavior patterns and routines, local traditions, flows and street life, opening hours, descriptions of noise and smell, and the café culture. The results can be visualized in a model that illustrates that each narrative level (text) contributes differently, but equally importantly, to the spatial analysis (Figure 6).

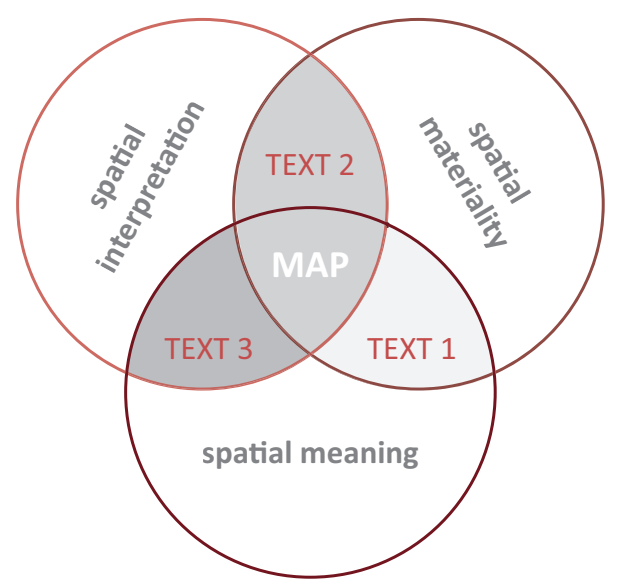

Figure 6. Map deconstruction model: Presenting the contribution of the three texts to spatial identity.

\section{Translation Into Urban Design Sketch Maps (III)}

To convert the tourist maps into urban sketch maps, the data was evaluated and translated into the five picture element types mentioned by Lynch (1960): paths, districts, edges, landmarks, and nodes (Figure 7). Lynch (1960) describes (1) paths as routes along which people move throughout the city; (2) edges as boundaries and breaks in continuity; (3) districts as areas branded by common characteristics; (4) nodes as strategic focus points for orientation, like squares and junctions "into which an observer can enter, and which are the intensive foci to and from which he is traveling" (Lynch, 1960, p. 47); and (5) landmarks as external points of orientation, usually an easily identifiable physical object in the urban landscape:

(1) Paths: The Charles Helou Road (a), which runs from East to West Beirut, was identified as a high-frequency path. Branching off from Charles Helou road to the south are George Haddead (b) and El Shouhada/Damascus Road (c). Parallel to Charles Helou and also with high frequency is Gourald/Armenia Street (d). Parallel, but with lower frequency, runs Charles Malek/Sagesse (e).
Branching off from Gourald Street is the St. Nicolas side pass (f). It has been recognized as a strong path all the way to Sursock Street (g).

(2) Edges: The main road Charles Helou separates the district in the north, further functioning as a border from the district direction port. As such, it is identified as an edge.

(3) Districts: Officially being two districts, Gemmayze and Mar Mikhael (h) appear as one section of the city with a hotspot along Gourald Street. The area in the south is the beginning of Achrafieh (i), another district separated by Malek/Sagesse. In the west borders, one can find the Central District (j).

(4) Nodes: The main road Charles Helou contains the only official station Charles Helou (k) for buses to Jordan, Syria, and beyond, an essential node for cross-border mobility. A node in leading into the district from the west is the intersection of George Haddead and Gourald (I). The long Gourald gets less monotonous through an additional node $(\mathrm{m})$ at the St Nicolas stairs, a local hangout and hub for cultural and social events.

(5) Landmarks: The area of observation contains various landmarks, iconic sights, and attractions. Defined landmarks are the Sursock Museum (1), the Sursock Palace (2), the St Nicolas Steps (3), and the St Elian Gregor Cathedral (4). Not in the district of Gemmayze and Mar Mikhael but still in our observation area are landmarks such as the Martyrs' Square (5), the famous Al Amin Mosque (6), the St Georges Crypt Museum (7), and the Cardo Maximus (8). Furthermore, described as iconic sights are the Grand Meshmosh Hotel (9) and the famous restaurant Mayrig (10).

Through the extraction of the program of the local it becomes visible that the neighborhood duo is an essential cultural component of Beirut, not least because of its landmarks, iconic sights, and attractions, but also because of the collection of boutiques, studios, galleries, open-air events, art projects, exhibitions, and other cultural events. Twelve cultural attractions are marked in the maps (Galerie Tanit-Beyrouth, Goethe Institute, Joy Mardini Design Gallery, escape the room, the Artlab, the Art on 56th gallery, 392 Rmeil, Alaliays bookstore, Metropolis Art Cinema, Artisan du Lebanese, Villa Audi Museum, and Lebanese Emigrants Statue). Furthermore, there are 16 cafés and restaurants (Urbanista, Cortado, Oslo Icecream, Kahwet Leila, Le Petit Gris wine bar, Dar el Gemmayze, Arteen, Meats \& Bread, Zimi, Sursock Resto, Marinella, Travolina, Le Chef Kehwet Leila, Bab Sharki, Loris, and Mayrig). There are also seven hotels and hostels (Talat Hostel, Al Nazih Hostel, Saifi Suites, 


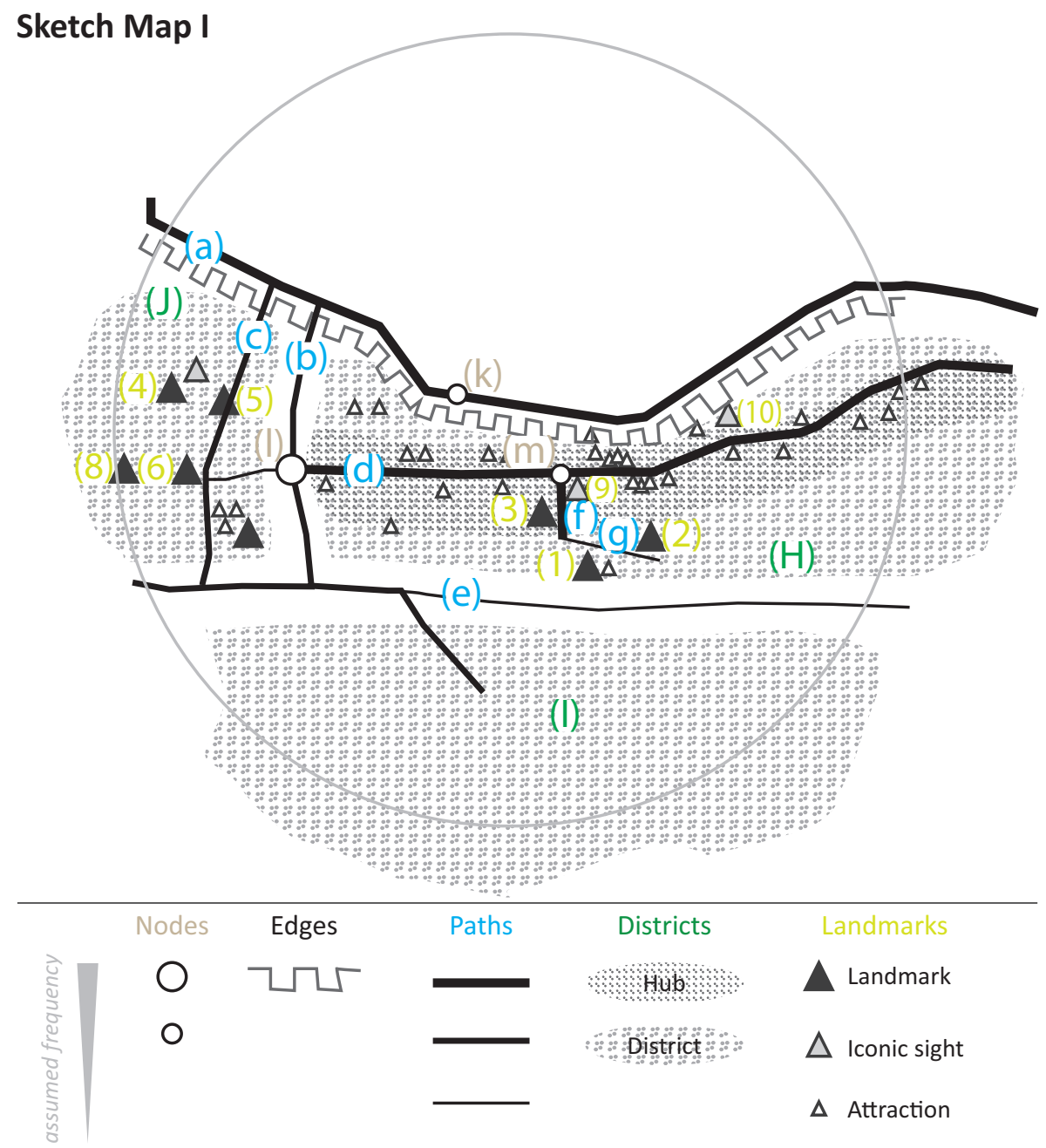

Figure 7. Sketch map I: Port blast area and tourist maps translated into a sketch map.

Saifi Urban Gardens, The Private Hotel, and The Grand Meshmosh Hotel), and nine shopping boutiques (Mra Hayak, Vanina, Plan B, Dehab Jewellery, Maison Rabih, L'artisan Liban, Cynthis Raffoul Jewelery, Nada Debs, Ateliers S). Moreover, the area contains six schools (Sacre Coeur College, Pigier School, Three Doctors School, La Sagress School, Beirut Annunciation School, and one is nameless).

Considering the high density of hostels and hotels, it is logical to conclude that tourists are major players in the area. High-priced restaurants and cafes indicate a middle and upper-class audience. The rich cultural and culinary program attracts a heterogeneous audience composed of students, working people, food and culture tourists, and locals.

The opening hours of the restaurants, cafés, boutiques, galleries and museums, and clubs match rush hours and flows. Restaurants and cafés are open from 8 am to $12 \mathrm{pm}$, stores from 9:30 am to $7 \mathrm{pm}$, museums from 9 am to $6 \mathrm{pm}$, and clubs open at $6 \mathrm{pm}$ and close no later than $3 \mathrm{am}$. During the day, café culture is the primary activity; work meetings, a quick lunch, backgammon, and card games are each and all part of the daily routine of the neighborhood's attractions. The peak traffic period for pubs and restaurants is observed from early to late evening hours on each day of the week. Street life is dominated by people in the evening when the bars open their outdoor tables. The area offers a famous and beautiful urban retreat for community activities or romance in fast-paced and chaotic Beirut (Ham et al., 2019).

Upon closer investigation, it can be understood that the neighborhood also plays an important role in international politics, in that it houses the House of the European Union, the Australian, Swiss, and Argentine embassies, and the Ministry of Foreign Affairs. Furthermore, it is also home to the Electricite du Liban Tower, the Haddad Hospital, two Red Cross stations, nine pharmacies, 20 ATMs, and a post office.

The analysis of religious sites-knowing that Beirut's fragmentation is still dominated by religious and political affiliation (Davie, 1994)-reveals that the only three mosques (Al Omari, Amir Assaf, and Al Amine) are in the central district (j). The area of Gemmayze and Mar Mikhael is predominantly Christian, containing 11 of the 17 churches (Figure 8): St Elie Greek Catholic (4), 


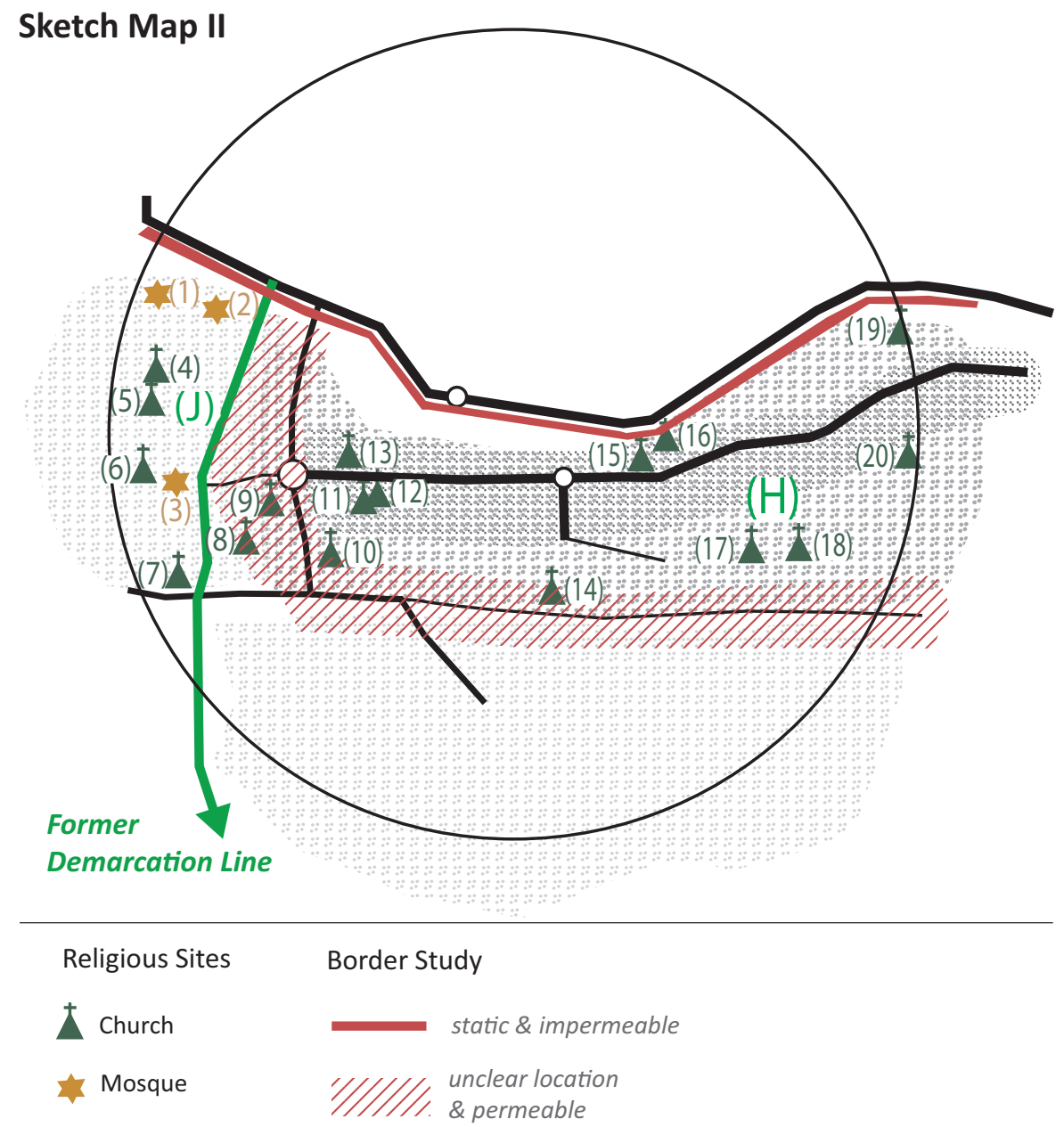

Figure 8. Sketch map II: Port blast area's religious sites and border study.

St George Orthodox (5), St George Maronite Cathedral (6), Mar Mansour (7), St. Elie-Church (8), Saint Elias and Saint Gregory the Armenian Catholic Cathedral (9), Mar Maroun (10), Santa (11), St Joseph (12), Sacre Coeur (13), St Nicolas Greek Orthodox (14), St Antoine Greek Catholic (15), St Antoine Maronite (16), St Joseph (17), St Georges (18), Mar Mikhael (19), and St Tresissios (20).

The overlay of the cognitive map with the former demarcation line shows an overlap with the identified border, marking the district's limits to the west. This may indicate that the former Green Line still functions as an intangible boundary. However, since Gemmayze and Mar Mikhael are known for their international audiences and are popular gathering places for locals, it can be assumed that the boundaries with neighboring districts are permeable, leading to the conclusion that the religious affiliation of the audience does not affect accessibility.

Nevertheless, limitations of the technique became visible when comparing the cognitive map with a sketch map of the area after the blast (Figure 9). The explosion in the port changed the physical environment of the area and therefore the cognitive map of the city's residents. The above analysis showed that the port was not part of the promoted sketch map, nor played a decisive role in defining the identity of the area before the blast. This demonstrates the power of white liesthe withheld data-in tourist maps. The Charles Helou Street functioned as an infrastructural boundary separating the neighborhood duo from the port. The blast invalidated the border function of Charles Helou Street and expanded and altered the cognitive map of the area. The contours of the neighborhood expanded to include the port, which is now inextricably linked to the site. In fact, the roadside fence of the Charles Helou Street is now an edge that connects the port to the neighborhood, like the balustrades in a theater that separate the audience seats from the auditorium. The shortcuts between Gourald Armenia Street and Charles Helou Street became high-frequency paths and nodes, even meeting points and places to view the silo from a distance (Figure 10.1).

The blast destroyed the physical landscape and with it the area's attractions and landmarks. "New" landmarks that now dominate the cognitive map of the public emerged: the destroyed silo and the warehouses of the port, heavily destroyed buildings such as the Electricité du Liban (Figure 10.2), and old colonial houses (Figure 10.3). 
Sketch Map I
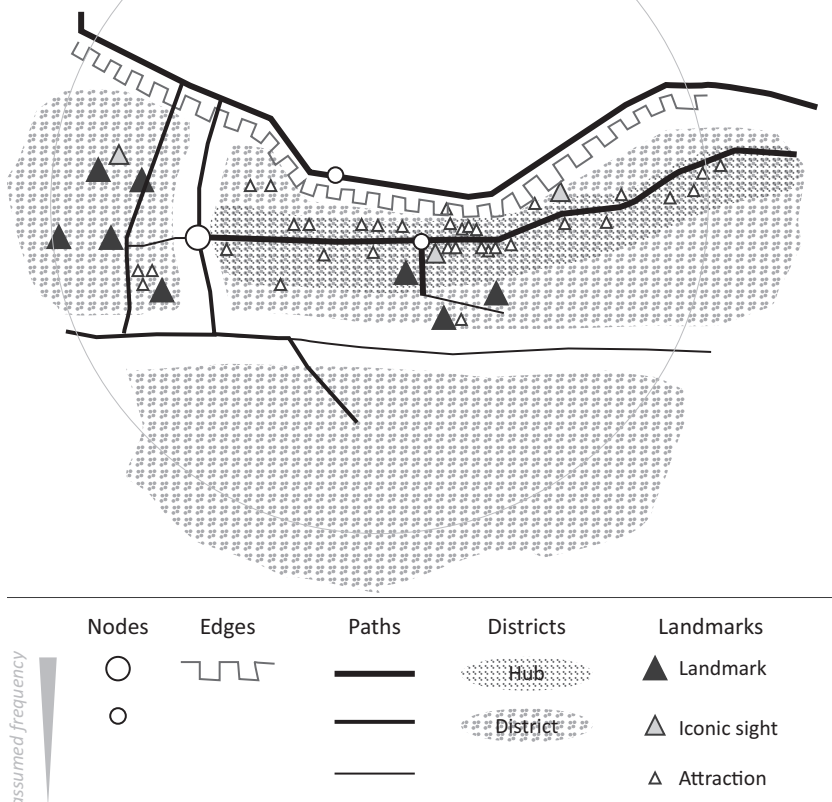

Landmarks

A Landmark

$\triangle$ Iconic sight

$\Delta$ Attraction

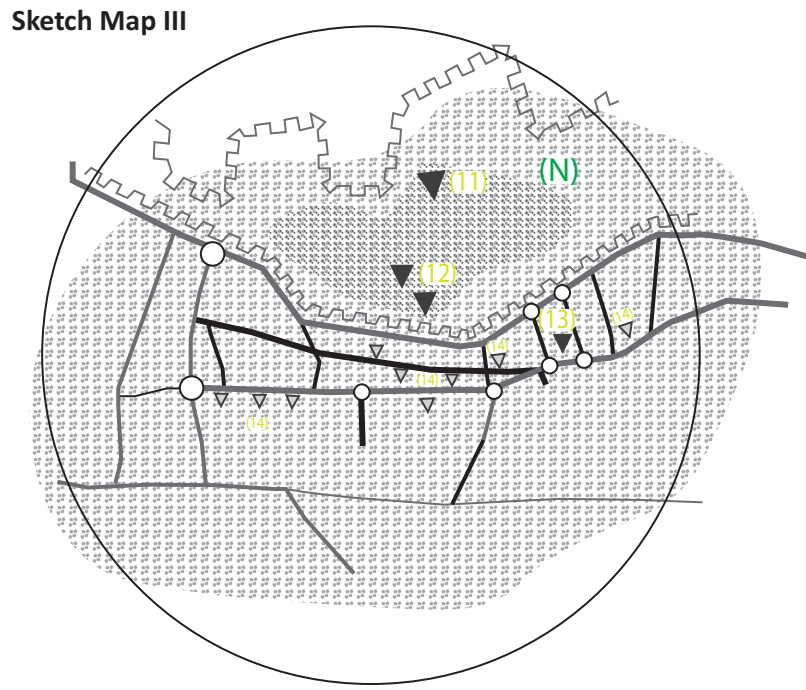

Figure 9. Comparison between sketch map I and III: Before (left) and after (right) the port blast.

\section{Conclusion}

In the past few decades, cities have become the transnational home for the majority of the world's population (Cuff et al., 2020). Urbanization and immigration flows are leading to new urban challenges. The spread of Covid-19 has exposed the negative effects of crossborder connectivity due to increased globalization. Stressful events on the local level, political upheavals, and unexpected disasters as presented in the case of Beirut can lead to a city-in-flux, characterized by rapid change and an unpredictable future. These complex urban challenges require interdisciplinary approaches by different agencies of spatial studies as well as the use of diverse media forms such as literature, photography, and film, all of which "[help] to make sense of the city and its people" (Cuff et al., 2020, p. 22).

This pilot study explores and opens up an unusual way of approaching and interpreting the city by reading it through a representational form: "the city in a map." The framework developed can help reveal zones, the possible pattern of fragmentation, the program and logic of the local from a distance in the absence of onsite observations. The features and structuring principles interpreted from the maps serve as indicators of spatial identity.
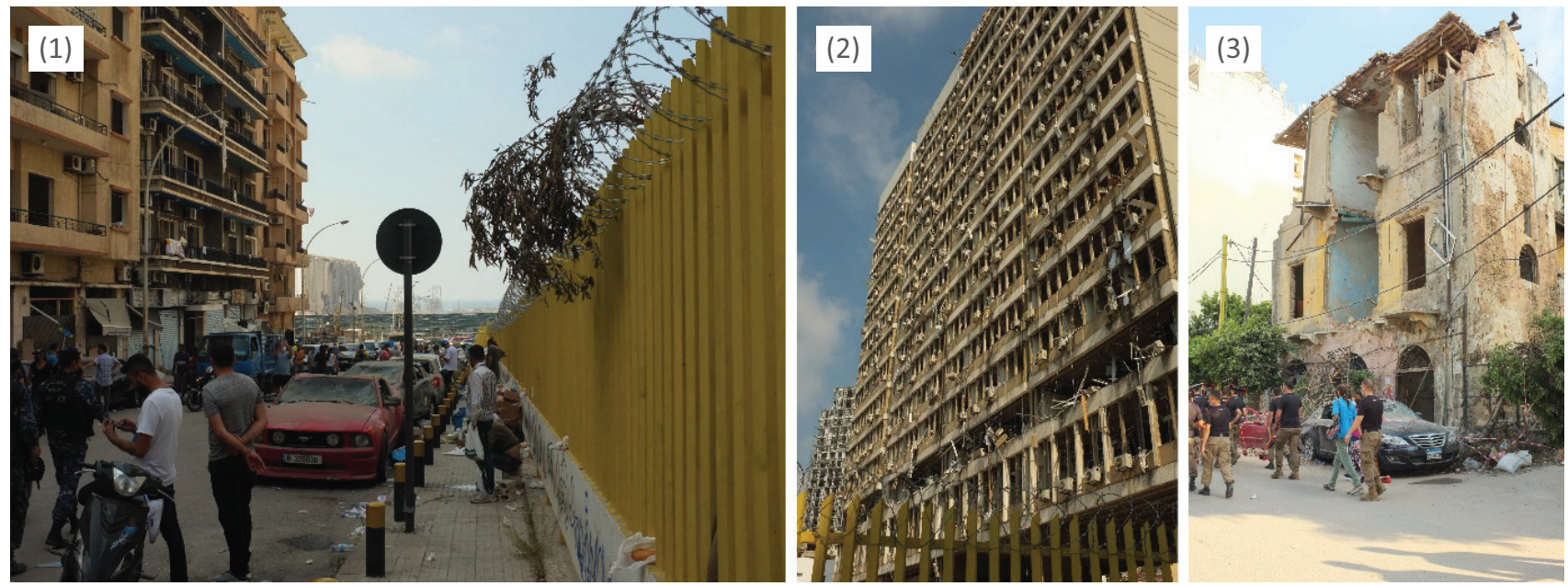

Figure 10. Photographs of the area after the blast: (1) Observing the silo from a distance, (2) Electricité du Liban, and (3) destroyed colonial houses. 
In the last decades, maps have evolved from ceremonial and decorative images to tools for way-finding. However, even if maps promise cartographic objectivity and accuracy through their level of detail, one must not forget that they are only a reflection of reality. Modified, simplified, and transferred into a two-dimensional drawing, maps are a human-made product whose creators have subjectively decided what is to be shown on the map and what is not. This results in the aforementioned white lies, which can distort or embellish reality. Map deconstruction shows that white lies due to missing data in tourist maps lead to white lies in the promoted sketch map. This raises the question of what gets lost in the process of reading a city through a secondary resource since, for example, a tourist map mainly shows the places of commercial, industrial, and cultural consumption. Indeed, one must raise the issue of authorship and its influence on the map's agenda. Does it contain power knowledge and how does the urban design agenda, which can be market-, social-, and activismbased, intersect with the primarily market-based agenda of tourist maps?

Beirut's physical state has changed extremely in these 200 days. Describing the city in its three phasescity of political upheaval, infected city, and port blast city-is, of course, an oversimplification of a much more complex and multi-layered reality. Such changes dramatically alter a city's image, but at what level does it really affect a city's identity? The current challenge for Beirut is not only the physical reconstruction of the destroyed areas, but also the preservation of the identity, internal logic, and social fabric of the places. I sincerely hope for responsible decision-making in the reconstruction process, as I wish nothing but the best for Beirut.

\section{Acknowledgments}

My acknowledgement and sincere gratitude are addressed to my first and second supervisors, Professor Robert Saliba (Department of Architecture \& Design, American University of Beirut) for his admirable academic support, guidance, and generous time, and Professor Angela Million (Department of City \& Regional Planning, Technische Universität Berlin) for supporting my decision to embark on this journey to Beirut, adding her valuable supervision during my exchange. Moreover, I would like to express a special attribution to Professor Emil Hädler from Mainz, who continually fosters my academic quests and professional path, and offered critical, mental, and technical support for my thesis, especially after the tragedy of the port blast. To Antoine Bou Dames, who was a devoted supporter and companion for my journey in Beirut. Furthermore, I would like to extend my heartfelt recognition to his family for their kindness and exquisite Lebanese hospitality. Last but not least, I address my sincere gratitude to my parents Edeltraud and Edgar and my brothers Marvin and Stefan for their endless support, love, and trust during this challeng- ing journey. I acknowledge the support of the German Research Foundation and the Open Access Publication Fund of TU Berlin.

\section{Conflict of Interests}

The author declares no conflict of interests.

\section{References}

Canter, D. (1977). The psychology of place. Architectural Press.

Carmona, M., \& Tiesdell, S. (2007). Urban design reader. Architectural Press.

Carmona, M., Tiesdell, S., Heath, T., \& Oc, T. (2003). Public places-urban spaces. The dimensions of urban design. Architectural Press.

Castillo, I. (2017). Space and radical planning: Linking protest action and local community self-development [Doctoral dissertation, Technische Universität Berlin]. DepositOnce. https://depositonce.tu-berlin.de/ handle/11303/10729

City Sightseeing Worldwide. (2021). City Sightseeing: World's leading hop-on hop-off tour operator. https://city-sightseeing.com/en/home

Cosgrove, D. (2004). Carto-city-mapping and urban space. In N. Möntmann \& Y. Dziewior (Eds.), Mapping a city (pp. 48-57). Hatje Cantz.

Cuff, D., Loukaitou-Sideris, A., Presner, T., Zubiaurre, M., \& Crisman, J. J. (2020). Urban humanities: New practices for reimagining the city. The MIT Press.

Davie, M. F. (1993, July 8-11). A post-war urban geography of Beirut [Paper presentation]. EURAMES Conference, Warwick, UK.

Davie, M. F. (1994). Demarcation lines in contemporary Beirut. In C. H. Schofield \& R. N. Schofield (Eds.), The Middle East and North Africa (pp. 35-58). Routledge.

Gale, N. (1982). Some applications of computer cartography to the study of cognitive configurations. The Professional Geographer, 34(3), 313-321.

Genberg, D. (2002). Borders and boundaries in postwar Beirut. In F. Colombijn \& A. Erdentug (Eds.), Urban ethnic encounters: The spatial consequence (pp. 81-96). Routledge.

Ham, A., Clammer, P., Crowcroft, O., Elliott, M., Isalska, A., Lee, J., Maxwell, V., Richmond, S., Robinson, D., Sattin, A., Raz, D., Symington, A., Walker, J., \& Water, S. (2019). Lonely Planet Middle East. Lonely Planet Global Limited.

Harley, J. B. (1989). Deconstructing the map. Cartographica: The International Journal for Geographic Information and Geovisualization, 26(2), 1-20. https:// doi.org/10.3138/e635-7827-1757-9t53

Jancewicz, K., \& Borowicz, D. (2017). Tourist mapsDefinition, types and contents. Polish Cartographical Review, 49(1), 27-41. https://doi.org/10.1515/pcr2017-0003

Kitchen, R. M. (1994). Cognitive maps: What are they and 
why study them. Journal of Environmental Psychology, 14, 1-19.

Lefebvre, H. (1991). The production of space. Wiley. (Original work published 1974)

Lynch, K. (1960). The image of the city. The MIT Press.

Monmonier, M. (1991). How to lie with maps. University of Chicago Press.

Neisser, U. (1976). Cognition and reality: Principles and implications of cognitive psychology. W. H. Freeman.

Norberg-Schulz, C. (1976). Genius loci: Towards a phenomenology of architecture. Rizzoli.
Relph, E. (1976). Place and placelessness. Pion.

Saliba, R. (2015). Urban design in the Arab world: Reconceptualizing boundaries. Routledge.

Saliba, R. (2020). Planning for resilience: Decoding and recoding Beirut's spatial patterns of fragmentation. Unpublished manuscript.

Tuan, Y. (1979). Space and place: Humanistic perspective. In S. Gale \& G. Olsson (Eds.), Philosophy in geography (Vol. 20, pp. 387-427). Springer.

Zawarib. (2020). Zawarib, the mapping company. http:// www.zawarib.org

\section{About the Author}

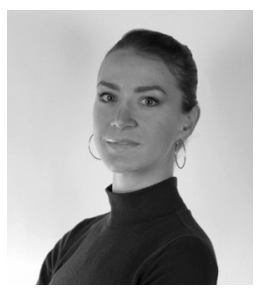

Laura Simak, born in Mainz, Germany, 1989, currently works as an experience strategist focusing on destination development in a Berlin-based company. Following graduating in 2015 with a Bachelor of Arts in architecture from the University of Technology in Mainz, Laura has contributed as both a lecturer and research assistant at the Architectural Institute. Published in 2017 by Deutscher Kunstverlag, she was in charge of the cartographic production at METACULT, a three-year transnational research project studying the cultural transfer in architecture and urban development in the case of Strasbourg. In 2020, she majored in urban design at the Technische Universität in Berlin while finalizing her master's thesis in Beirut. 